\title{
EDITORIAL
}

\section{Jacques Lacan and French psychiatry ${ }^{1}$}

Jacques Lacan died in September 1981 at the age of 81 . The French press, the mass media and several members of the French government all paid him tribute. For several years his name had been linked with that of Sigmund Freud, and he was often referred to as the French Freud. Students of medicine and the social sciences studied his writings, or pretended to read them. Even some secondary school children knew 'le nom du père' (the father's name) as a 'signifier of the Phallus'.

Sherry Turkle (1978; and see Psychological Medicine, 1980) has described for English-speaking readers "the invasion of French intellectual life by psychoanalysis and the way in which French culture has remade it in their image'. In her opinion, Lacan was the mainspring of this invasion. In his review of Turkle's book James Gammill (1979), mentioning that certain social and cultural conditions are necessary for so wide a diffusion of ideas, showed how an exceptional psychoanalyst like Lacan may play a disrupting and perhaps a vitalizing role.

This editorial traces the first steps of psychoanalysis in France, the special part played by Lacan in French psychiatry and culture, and his psychoanalytical development. I shall also try to describe his effect in recent years and to indicate why he influenced psychiatrists, philosophers and intellectuals.

I do not wish to discuss the value of his contribution to psychoanalysis, or to explore the reasons why he was expelled from the French psychoanalytical societies and from the International Association of Psychoanalysis. It is enough to say that these decisions seemed necessary for ethical reasons, and especially because of the extreme brevity of the sessions which he conducted with his analysands.

\section{THE BEGINNINGS OF PSYCHOANALYSIS IN FRANCE AND THE PLACE OF LACAN IN FRENCH PSYCHIATRY AND CULTURE}

The Paris Psychoanalytical Society was founded in 1926 and several psychiatrists were then trained, particularly by Loewenstein who came from Berlin to help one of the founder members, Marie Bonaparte. Lacan was among these young psychiatrists, working with, among others, Henri Ey in a new group, L'Évolution Psychiatrique. These psychiatrists had received a classical training in psychiatry. Lacan also worked with de Clérambault, at the time a very important figure in French psychiatry, who supervised Lacan's (1926) medical thesis on 'Paranoid psychosis and its relationship with the personality' in which he described the case of Aimée who tried to kill a well known actress. During this period Lacan was moving in artistic and intellectual circles. Although a friend of André Breton, the surrealist leader, he was expelled from this movement when he agreed to hold his first wedding in a Catholic church. Before World War II Lacan was also interested in some aspects of philosophy, though it is difficult to assess his knowledge of this field. He learnt some German and appears to have been familiar with Hegel's work.

Before the second World War Lacan gave a paper to the International Psychoanalytical Congress and wrote an important chapter on the family, under the direction of Henri Wallon, in the Encyclopédie Française (Lacan, 1938). It may be noted that, in a critique of this paper, Pichon (1939), a psychoanalyst who was a member of a right-wing political organization, congratulated Lacan for formulating the notion of a specifically 'French psychoanalysis' which should eliminate 'German' ideas on childhood sexuality. In retrospect, Pichon's comments anticipate what was to come.

1 Address for correspondence: Professor S. Lebovici, Hôpital Avicenne, 125 Route de Stalingrad, 93009 Bobigny, France. 
After the war, Lacan was re-introduced at the first meetings of the Paris Psychoanalytical Society. He was not well received and candidates who applied for training were advised not to choose him as an analyst.

Conflicts soon arose in the Institute of Psychoanalysis, founded by Nacht. In 1953 Lagache and four other psychoanalysts left the Paris Psychoanalytical Society. Lacan was not aware of their decision, but soon followed them to form a new Société Française de Psychanalyse. In 1962 this Society was accepted as a member of the International Association on the condition that Lacan would cease to be a training analyst. He then founded L'École Freudienne de Paris, composed at first of a small number of friends. The size and influence of this group were to be explosive. Its growth was characterized by a sort of group parthenogenesis. Contrary to the usual pattern of psychoanalytical societies, where there is a clearly-defined curriculum with regular evaluation, Lacan pleaded for total freedom. In the École Freudienne the responsibility to become an analyst remained in the hands of each analysand, without any selection, though at the same time a long process of assessment was planned for would-be 'members'. After this long period of evaluation, limited to the elite, future members were finally accepted by Lacan himself.

In 1979 Lacan announced the dissolution of the École Freudienne. He wrote a letter to some 2000 disciples, more than a thousand of whom indicated their willingness to follow him in a new group, 'la cause freudienne', a title chosen to recall Freud's 'die Sache'. In this letter proclaiming his decision to continue he linked the statement 'je persévère' (I continue) with 'père-sévère' (severe father), a play on words to underline his paternal role. This Lacanian style became very popular in France, not only in the psychoanalytical literature but in many other writings, where the words were cut to play with the 'signifier', in accordance with his use of de Saussure's linguistic theory.

In the past 15 years the Lacanian group has increased greatly in size. Though the links between psychoanalysis and therapy were ignored, a significant number of Lacanian 'psychotherapists' were disseminated in France without any clinical training. After the death of the 'Maitre', the disciples have clustered in many groups, all proclaiming their true and unique understanding of his teachings. Lacan's son-in-law, Jacques Alain Miller, is currently preparing the publication of new books, derived from 'the Seminar', and has been accused of having kept Lacan a prisoner in his later years.

It is helpful to have an idea of the atmosphere created by Lacan to understand his influence. During his association with the Freudian School, he gave seminars which were crowded with young psychiatrists, psychologists, prospective analysts and a variety of representatives from social intellectual circles. There was also a sprinkling of young and elegant women. This type of gathering continued a very French tradition: in his time Henri Bergson evoked the same kind of admiration at the Collège de France. In the course of his seminars Lacan delivered 'the good word' in his own individual way. On some occasions he remained silent and the audience waited anxiously for his pronouncements. In some sessions the 'Maître' criticized some of the papers by his followers or simply provided an interpretation to one of his analysands. He gave the same impression when he appeared for a series of presentations on French television.

\section{LACAN, FRENCH PSYCHIATRY, PSYCHOANALYSIS AND CULTURE}

When Jacques Lacan founded his Freudian School, he pleaded for a return to Freud. His clear intention originally was to criticize the French translations of Freud. Several of these were admittedly very poor or even misleading, but some French psychoanalysts have since begun to work on these translations. The vocabulary prepared by Laplanche \& Pontalis (1967) was the first expression of such work. In this field Lacan's impact was probably useful. His contribution may be illustrated by reference to the word negation (in German 'Verneinung'). The word 'Verleugnung' was translated into French by the same word, negation or denegation. The English Standard Edition (Freud, 1962, p. 143) proposed another word, i.e. disavowal. It was necessary to find a specific word in French in order to qualify this negation of something pertaining to external reality (cf. Laplanche \& Pontalis (1967) La négation, p. 113). Lacan added the word forclusion to translate the word 'Verwerfung' (repudiation) to describe the primary rejection of a 'signifer', for instance 
the phallus, as a signifier of castration, apart from symbolic thinking. This example demonstrates the distinction between serious work and a forced interpretation.

By means of this approach Lacan employed in a most unusual way the idea that 'the unconscious is structured as a language'. He pleaded for the structural study of the verbal productions of the analysands, asserting that the interpretations may and must use the verbal forms, the signifiers. This play with words and their phonemic structure was to become a kind of game for many French intellectuals.

The Lacanians are not preoccupied with the therapeutic value of psychoanalysis or psychoanalytical psychotherapy, and their position carries a number of consequences. (i) It becomes possible to claim that a childhood psychosis expresses the mother's unconscious desire without taking any neurobiological considerations into account and neglecting the severe guilt with which parents can be saddled by such opinions. (ii) Freud's metapsychological papers are more interesting than his clinical or technical writings. This view contrasts with that of the English and American psychoanalysts, who are concerned with the discussion of precise clinical material.

These general traits, however, appeal to some French psychiatrists, psychoanalysts, and specialists in the human sciences because of their passion for speculation. The Lacanian outlook is close to that of other contemporary French international preoccupations - for example, structural linguistics or structuralism - and in his own way Lacan used the work of friends like Lévi-Strauss and Foucault.

Having worked with the French psychologist Wallon, Lacan made use of his observations on the baby in front of the mirror and, without quoting Wallon, he described the state of the mirror which, he proposed, is the source of the Ego (Lacan, 1949). The object relation becomes a relation to the 'other', then to the 'Other'; this transition may lead to numerical formulations, and mathematical modelling becomes possible. Lacan also drew on personal information concerning Freud and his family to propose various interpretations of his work and his writings.

By such means Lacan adapted aspects of other disciplines in the field of human sciences, presenting them in his own way and sometimes persuading their originators to accept his concepts. In this task his poetic and provocative verbal style played an important part.

Lacan's basic proposal was to adopt an hermeneutic approach to Freud's work (Ricoeur, 1965). For this purpose he mobilized the power of words, which was to prove so important during the so-called student revolution of 1968 . He deplored the subordination of psychoanalysis to medicine and psychiatry, and was extremely critical of American psychoanalysis. Smirnoff (1979) has given a clear account of the route from Vienna to Paris. Lacan went further than Pichon (1939) in attacking the whole psychoanalytical establishment and presenting himself as an enemy of those psychoanalysts who argued for a rapprochement with society. With his ambiguous declarations he aroused the sympathy of many intelligentsia of the political left who paid tribute to him as the French Freud.

\section{CONCLUSION}

Although I am aware of the dangers of extrapolation from a single case, some metaphorical significance may be discerned in the following clinical vignette.

A young Jewish psychiatrist in training analysis declared a wish to find his own identity. For this reason he intended to learn Yiddish from his mother, but only after his father's death. In reality he had begun lessons before this event and his mother, along with other elderly ladies who had known him during his childhood, were able to regard him as 'the best of sons'. At the same time, he demonstrated a curious ignorance of the Old Testament and repudiated its cultural value. This refusal coincided with a disinclination to commence psychoanalytical training.

It was not difficult to interpret this behaviour as a way of seducing the mother and opposing the father's authority, despite the subject's pretensions. It is unnecessary to add that he often told me that he would eventually prefer to have a Lacanian training. This material seems to me pseudooedipal and characterizing an avoidance of the Oedipal situation (Lebovici, 1982). André Stephane (a pseudonym for B. Grumberger and J. Chasseguet (1969)) has described the same psychological organization of students engaged in the May 1968 revolution in Paris. Freud himself 
describes the process of secondary identification needed for the study of the resolution of the Oedipal situation. It is neither a form of imitation nor of incorporation, but a long drawn-out process in which introjection and extrojection are at work.

The followers of Lacan contemplate a mother-god at the same time as they profess themselves to be the true heirs of Freud, whose teachings they reject in many respects. In particular, Freud emphasized two points: (i) psychoanalysis is not one 'Weltanschauung'; (ii) psychoanalysis is not a form of 'Geistenwissenschaft' but a 'Naturwissenschaft'. He was himself a Darwinian and worked, he maintained, in the same direction as his teachers, neurophysiologists like Brücke and Haeckel (Natural History, 1868). I have tried elsewhere to show how Freud tried to anchor man in a biological foundation (Lebovici, 1981).

At present in France, as in many countries, it is often said that the world as a reality no longer exists and that the observer and his perceptions are engaged in a temporal process (Prigogine \& Stengers, 1979). The classical concepts of the natural sciences, arising from the work of Copernicus, Newton and Darwin, are questioned from many viewpoints. Freud has discussed the narcissistic wounds which these scientists inflicted on man's megalomania. I would dare to suggest that this 'narcissistic wound' can be detected in French political life since the last World War. The French put their trust in a providential figure and then rejected him. It may well be that the events of May 1968 constituted an expression of this rejection, as was the case in May 1981 when the political changes were attributable to feelings of inequality and injustice on the one hand, and, on the other, to some Utopian trust in democracy obtained via decentralization and the creation of new centres of power.

Frenchmen with a hatred of the establishment and the so-called American influence have discovered and revered Lacan, hoping that he would be able to create a French psychoanalysis. After his death they have divided themselves into many small groups, cultivating 'the narcissism of little differences' and quarrelling among themselves like feudal subjects without a king.

The true Freudian legacy is an invitation, not to a hermeneutic interpretation but to one renewed by new experiences and findings. For Levy, one of the 'new philosophers' and a self-declared Lacanian, the 'God Testament' (1979) is concerned with the death of God and His transmitted text. As we learn from the family approach in psychiatry, there is a genuine transmission from one generation to another. Within psychotic families attempts are made to avoid transgenerational conflicts and to conceal the so-called family secrets in order to maintain a state of homeostasis. It seems to me that the same process characterizes the Lacanian 'family'.

The French newspaper Le Monde has recently (1982) published three articles on Lacan's influence in France. Jaccard (1982) describes how psychoanalysis has become a new French culture. He detects the impact of May 1968 and describes how the French, conditioned by their secondary school education to a 'textual explanation' and to quotations, are primed to accept the Lacanian analysis of a text on the unconscious. Moscovici (1982) offers an equation:

$$
\text { Lacan }+ \text { May } 68+\text { Modernism }=\text { France. }
$$

He sees in France a new area of cultural space in which Lacan takes his place with such figures as Foucault and Barthes. For these men, according to Moscovici, the events of May 1968 have given a political meaning to various movements, including anti-psychiatry and feminism, and have brought about what he calls a series of social events. De Mijolla (1982) thinks that Turkle's portrait of French psychoanalysis clearly indicates that something must now be done, declaring there to be no equivalence between Freudian, Lacanian and psychoanalytical systems. Psychoanalysis itself is more important than its various cultural forms.

These authors confirm the opinion that the Lacanian movement is a Parisian phenomenon linked with political movements which reached their climax in May 1968. More than a form of psychoanalysis à la française, it represents a form of conjunction between one man and his milieu, in which the transmission of psychoanalysis becomes problematical.

They say: 'God is dead.'

I tell them: 'No, the king is naked.' 


\section{REFERENCES}

Freud, S. (1962). The Ego and the Id and Other Works (transl. J. Strachey and A. Tyson). Hogarth Press: London.

Gammill, J. (1979). Book review. International Review of Psychoanalysis 6 (4), 515-517.

Jaccard, R. (1982). Une nouvelle culture psychanalytique. Le Monde 26 March.

Lacan, J. M. (1926). La psychose paranoiaque dans ses rapports avec la personnalité. Thèse Médecine: Paris.

Lacan, J. M. (1938). La famille et la vie mentale in Encyclopédie Française, La vie mentale II, A (ed. A. de Monzie). Larousse: Paris.

Lacan, J. (1949). Le stade du miroir comme formateur de la fonction $\mathrm{du}$ je, telle qu'elle nous a été révélée dans l'expérience psychanalytique. Revue française de Psychanalyse 13 (4), 449-455.

Laplanche, J. \& Pontalis, J. B. (1967). Vocabulaire de la psychanalyse. Presses Universitaires de France: Paris.

Lebovici, S. (1981). Une lecture en 1981 de l'article de S. Freud: Une difficulté sur le chemin de la psychanalyse (1917). Revue française de Psychanalyse 6, 1291-1313.

Lebovici, S. (1982). Origine et développement du complexe d'Oedipe.
Presented at the 32nd International Congress of Psychoanalysis. International Journal of Psychoanalysis (in the press).

Levy, B. H. (1979). Le testament de Dieu. Grasset et Fasquelle: Paris. Mijolla, A. de (1982). Transes et modes parisiennes. Le Monde 26 March.

Le Monde (1982). La France sur le divan; 26 March.

Moscovici, S. (1982). Lacan expliqué aux Americains. Le Monde 26 March.

Pichon, E. (1939). La famille devant J. M. Lacan. Revue française de Psychanalyse 11 (1) 107-135.

Prigogine, I. \& Stengers, I. (1979). La nouvelle alliance. Gallimard: Paris.

Psychological Medicine (1980). Book review: Psychoanalytic Politics; 10, 395.

Ricoeur, P. (1965). De l'interpretation. Le Seuil: Paris.

Smirnoff, V. (1979). De Vienne à Paris. Nouvelle Revue de Psychanalyse 20, 13-54.

Stephane, A. (1969). L'univers contestationnaire. Payot: Paris.

Turkle, S. (1978). Psychoanalytic Politics: Freud's French Revolution. Basic Books: New York. (La France freudienne (transl. Y. Tenenbaum). Grasset: Paris. 1982.) 